\title{
A Literature Review on Institutional Change and Entrepreneurship
}

\author{
Jin Tao \\ IEL-Institutions, Economics and Law Program, University of Turin, Turin, Italy \\ Email:mlbsabc@sina.com
}

How to cite this paper: Tao, J. (2016) A Literature Review on Institutional Change and Entrepreneurship. Open Journal of Business and Management, 4, 629-648. http://dx.doi.org/10.4236/ojbm.2016.44064

Received: June 4, 2016

Accepted: August 27, 2016

Published: August 30, 2016

Copyright $(\odot 2016$ by author and Scientific Research Publishing Inc. This work is licensed under the Creative Commons Attribution International License (CC BY 4.0).

http://creativecommons.org/licenses/by/4.0/

(c) (7) Open Access

\begin{abstract}
The literature argues that what is an institution, how institution changes, and the relationship between institutional change and entrepreneurship. I argue that institution is not only the rule in a hierarchical order, but also a rule as something spontaneously and endogenously shaped and sustained in the repeated operational plays of the game itself [1]. Culture and meaning are important in the definition of institution. An institution conceptualized is essentially endogenous, but appears to be an exogenous constraint to the individual agents [2]. Paths of in institutional change have two ways: Demand Induced Change-Bottom-up Change or Supply Induced Changes: Change from above and from outside. Entrepreneurship does an important role during institutional change. Most of researches about the relationship of entrepreneurship and institutional change are how nation's institution or economic policy influence entrepreneurship, and how entrepreneurs' actives make the economy successful or unsuccessful. I argue that entrepreneurship is not only concerned with business success, as measured by profits, but also with subjective welfare and noneconomic wellbeing. Entrepreneurship is a catalyst for structural change and institutional evolution. Evasive entrepreneurs could be viewed as a new rule-breaker. In most theories of institutions and entrepreneurship, causality is understood to run from institutions to entrepreneurship [3].
\end{abstract}

\section{Keywords}

Institutional Economics, Institutional Change, Entrepreneurship

\section{What Is an Institution?}

Theory of institutional change is important because economics deals with institution. The theory of institutional change is highly important for further advancement in the social sciences in economics and in general [2]. Searle gives the reason: economics as a 
study of the disposal of scarce commodities, is largely concerned with institutional facts, because the mode of existence of the "commodities" and the mechanisms of "disposal" are institution [4].

Institutions are defined of durable systems of established and embedded social rules that structure social interactions. Language, money, law, systems of weights and measures, traffic conventions and firms are all institution. A broad definition of institutions has now become widely accepted [5]: A widespread practice and define institutions as durable systems of established and embedded social rules that structure social interactions. Language, money, law, systems of weights and measures, traffic conventions, table manners, firms (and other organizations) are all institutions. The definition has been given not just by economists, but by the enormous number of social theorists who have been concerned with the ontology of society [4].

However, economists disagree on what institutions are. By now divergence still exists even among economists, which are quite important for discussing the main core of this dissertation.

\subsection{Neo-Institutionalists}

Neo-instiutionalists pay more attention on the definition of institution because they emphasize the function of institution to reduce transaction costs, increase economic efficiency. Economics matter is institutional matter.

Institutions are defined as rules-constraints or rules-routines by neo-institutionalists. The economic notion of "institution" understood as "constraints" is defined by Douglas North: Institutions are the humanly devised constraints that structure political, economic and social interaction, consisting of both informal constraints and formal rules, which have been used to create order and reduce uncertainty in exchange [6]. North considers "institution" as a rule of game, which can constrain human interaction with institution. Nelson challenges North's definition, and he defines institution as social technologies consisting of rules-routines, which mean specific ways of playing a game: An agent's rules-routines guide step-by-step, or operation-by-operation, the agent's behavior, with the lowest-level routines determining, possibly in function of some present or past conditions, the agent's actual actions [7]. The contrast between the two definitions can be enhanced by speaking of "rule-following" only for rules-routines, and use the term "rule-respecting" for rules-constraints.

Neo-institutionalists more approve North's definition. Pelikan approves North's definition: North's definition reduced to an operationally clear nucleus [8]. Rules-constraints set limits to large varieties of permissible behaviors and actions, which mean that within the constrained varieties, the agents are free to search the best strategy. Such a radical reduction is indeed necessary for allowing institutional economics to become rigorously analytical, with well-defined connections to other parts of economic analysis-in particular the theory of property rights, constitutional political economy, and the entire field of law and economics, where some of the most important practical applications of theoretical economic analysis are now being produced. Mokyr wrote for 
praising North in 2010: "institutions are essentially incentives and constraints that society puts up on individual behavior" [9]. The words "constraints" and "incentives" here matter a lot, because North and Levitt mean what all Neo-institutionalists economists mean by them.

It is also important to divide institutions into formal, such as written laws, and informal, such as unwritten social norms. Both are indeed humanly devised, but in different ways: formal institutions originate in deliberate legislation, or deliberate verdicts of courts, and informal institutions in spontaneous cultural evolution [1].Both the formal and informal rules of the game, and the manner and effectiveness of the enforcement of those rules influence the nature of markets. Institutions can be understood as the formal and informal rules governing human behavior [10].

Although neo-institutionalists have controversy about institution definition, they still have universality. They want to narrow the word "institution", maximization under constraints, and they are willing to keep ethics away [11].

\subsection{Critique of Neo-Institutionalism}

The universal peculiarity of the neo-institutionalists, including maximization under constraints and ignoring ethics or humanness, induce scorching refute. A new controversy emerged in new institutional economics: should institutions be defined as constraints, comparable to "the rules of a game", or as routines, meaning "specific ways of playing a game" [10]. If institutions are nothing more than human devised constraints, why can't badly-performing economies design good institution and implement them? McCloskey in Why Neo-Institutionalism can't explain the modern world gives two main reasons why she opposes North's definition [11].

The first reason is that people are rational, but not totally rational. Neo-institutionalists drag all human behavior under the lamppost of incentives simply by defining all of it as "rational", neo-institutionalists economics believe that we act as it seems most productive to act that way. Consumers and producers, the economists say, maximize utility "subject to constraints", or "in view of the incentives". The main character in North's story and the other neo-institutionalists, is always Max U, the prudent human. The idea of "rational behavior" or "economic man" was given by Adam Smith in The Wealth of Nations, he wrote: "It is not from the benevolence of the butcher, the brewer, or the baker that we expect our dinner, but from their regard to their own interest [12]". In the view of Adam Smith, self-interest is the nature, everyone in the society try to realize self-interest. Later, John Stuart Mill clearly put forward the "economic man", he pointed out "Economic man" is the one who can get maximum profit. Posner ultimately inherited and developed "economic man", which is the most important theory basis of traditional law and economics.

However, theory of bounded rationality from behavior economic provides the defect of rational economic man. Bounded rationality, as a framework for understanding and often modeling social and economic behavior [13], refers to the fact that human cognitive abilities are not infinite. Their limited skills and memories lead to bounded ratio- 
nality. Even people can deal with the limited skills and memories using the method of rationality, human behavior is still distinct with the prediction from the standard model of unbounded rationality. The departures from the standard model can be divided into two categories: judgment and decision-making. Bounded rationality let people make false decision in decision-making process. People tend to follow their own ideas to express or describe facts and other information. On the other hand, people's decision always shows that the results depart from the theory of expected utility theory.

Behavior is sometimes best described scientifically as being about incentives given to the social actors, but sometimes it is best described as Second-City improvisational comedy, with or without suggestions from the audience [11]. Complex and interacting system of norms, structures, and cultural understandings that shape individual and organizational behavior means the above simply rational is wrong. Definition of institution by neo-institutionalists, who believe that we act as it seems most productive to act that way, is not correct.

The second point, McCloskey points that institutions cannot be viewed merely as incentive-providing constraints. North and other economists do not usually notice that institutions do not merely constrain behavior, giving prices to which people have an incentive to respond. They also express humanness, giving it meaning. North ignores ethics or humanness, because they want to reduce to formulaic steps, maximization under constrains, rigid rules of the game known to all, the constrains being the institutions [14].

Neo-institutionalists about "institutions" or "incentives" do not mean what other socialists or anthropologists mean by institution, for instance, a typical definition is that provided by Jonathan Turne: "a complex of positions, roles, norms and values lodged in particular types of social structures and organizing relatively stable patterns of human activity with respect to fundamental problems in producing life-sustaining resources, in reproducing individuals, and in sustaining viable societal structures within a given environment". Again, Anthony Giddens says: "Institutions by definition are the more enduring features of social life, which includes institutional orders, modes of discourse, political institutions, economic institutions and legal institutions [15]". The contemporary philosopher of social science, Rom Harre follows the theoretical sociologists in offering this kind of definition: "An institution was defined as an interlocking double-structure of persons-as-role-holders or office-bearers and the like, and of social practices involving both expressive and practical aims and outcomes". Or some anthropologists wrote: "It was part of a whole complex, of moral ritual, customs with the force of law and the weight of sanctity". Sociologists use the term to refer to complex social forms that reproduce themselves such as governments, the family, human languages, universities, hospitals, business corporations, and legal systems.

Searle also deny "institution as constraints", he points that the essential role of human institutions and the purpose of having institutions is not to constrain people, but to create new sorts of power relationships. He writes: "What distinguishes human societies from other animal societies, is that human beings are capable of a deontology 
which no other animal is capable of... Without the recognition, acknowledgment, and acceptance of the deontic relationships, your power is not worth a damn". Three primitive notions are necessary to explain social and institutional reality: collective intentionality, the assignment of function, and status function. An institution is any collectively accepted system of rules (procedures, practices) that enable us to create institutional facts. An institutional fact is any fact that has the logical structure $\mathrm{X}$ counts as $\mathrm{Y}$ in $\mathrm{C}$, where the $\mathrm{Y}$ term assigns a status function and (with few exceptions) the status function carries a deontology. The creation of an institutional fact is, thus, the collective assignment of a status function. The typical point of the creation of institutional facts by assigning status functions is to create deontic powers.

Without a proper understanding of the morality and social conventions of the marketplace, the historian cannot understand the influence of formal institutions. Some economists grasp that institutions have to do with human meaning, not merely Northian constraints.

\subsection{Meaning and Humanness Are Important}

In North's definition of institution, institutions are the humanly devised constraints, people do rational choice to maximize their utilities under the constraints of institution, bounded rationality and humanness is not concerned. Institutions are not just constraints or incentives, meaning and humanness are important for defining institution when we consider how institutions take shape.

The question "in what manner social order itself arises" is answered by Luckman and Berger: "social order is an ongoing human production. It is produced by man in the course of his ongoing externalization [16]. Social order, needless to add, is also not given in man's natural environment, though particular features of this may be factors determining certain features of a social order". Luckman and Berger emphasize habitualization and its typification.

The examples Schutz gives of institutions are communication between two men: "Thoughts are constructed gradually and are interpreted gradually. Both speaker and listener live through the conversation in such a manner that meaning-establishment or meaning-interpretation are filled in and shaded with memories of what has been said and anticipations of what is yet to be said. When interpreting signs used by others, we will find two components involved, the objective and the subjective meaning. Speaker's choice of words will depend on the habits he has built up in interpreting the words of others, but also be influenced by his knowledge. For listener, he can start out with the objective meaning of the words he has heard and from there try to discover the subjective meaning of the speaker. In order to arrive at that subjective meaning, he imagines the project which the speaker must have had in mind".

This kind of communication gradually generated collective intention, and then became habitualization. Habitualization depending on language, tradition, former knowledge became typification. Institutionalization occurs whenever there is a reciprocal typification of habitualized actions by types of actors. Searle also raises a similar definition that an insti- 
tution is any collectively accepted system of rules (procedures, practices) that enable us to create institutional facts:

These rules typically have the form of $X$ counts as $Y$ in $C$, where an object, person, or state of affairs $X$ is assigned a special status, the $Y$ status, such that the new status enables the person or object to perform functions that it could not perform solely in virtue of its physical structure, but requires as a necessary condition the assignment of the status.

Considering institution just as a human devised constraint is not a proper way to understand institutional change and how institutionalization happens. Meaning depending on personal experience, humanness or deontology, and knowledge, which is sometimes called "understanding of the other self", as is the classification of others' behavior into motivation contexts, is important for institution and institutional change. Institutional ontology is subjective, it must always be examined from the first person point of view, people have to be able to think oneself into institution to understand it. Searle opposes North's definition: the essential role of human institutions and the purpose of having institutions is not to constrain people as such, but to create new sorts of power relationships. It is the power that is marked by such terms as: rights, duties, obligations, authorizations, permissions, empowerments, requirements, and certifications. What distinguishes human societies from other animal societies is that human beings are capable of a deontology which no other animal is capable of.

Not all deontic power is institutional, but just about all institutional structures are matters of deontic power. Without the recognition, acknowledgment, and acceptance of the deontic relationships, your power is not worth a damn.

Grannovetter also emphasizes that the personal experience of individuals is closely bound up with larger-scale aspects of social structure, well beyond the purview or control of particular individuals [17]. Institutions control human conduct by setting up predefined patterns of conduct, which channel it in one direction as against the many other directions that would theoretically be possible [18]. As a consequence, institution is not just a constraint devised by human and allows the neo-institutionalists to lay down the future. The definition of institution must consider the humanness, deontology and the meaning.

North's definition reduction is indeed necessary for allowing institutional economics to become rigorously analytical, with well-defined connections to other parts of economic analysis, ignoring meaning always generates inaccurate understanding of institutional change.

However, if we are interested in the process of institutional evolution, we need to depict institutions not as exogenously given constraints but rather as the outcome of individual interaction. Also as Clifford Geertz and his colleagues put it, an institution such as a toll for safe passage is "rather more than a mere payment", that is, a mere monetary constraint. "It was part of a whole complex of moral rituals, customs with the force of law and the weight of sanctity" [14].

Neo-instituitionists should not just consider institution as a constraint which can be 
computed and find the maximum to maximize the profit. Institution is not only the rule in a hierarchical order, but also a rule as something spontaneously and endogenously shaped and sustained in the repeated operational plays of the game itself. An institution conceptualized is essentially endogenous, but appears to be an exogenous constraint to the individual agents [2]. Institution compulsively carried out by central government without matching the culture and human meaning hardly sustains.

\section{Institutional Changes}

As we talked in the definition of institution, an institution, essentially endogenous, but appears to be an exogenous constraint to the individual agents. An object, person or state of affairs is assigned a special status, such that the new status enables the person or object to perform functions that it could not perform solely in virtue of its physical structure. When we focus on the process of institutional evolution, it is important to define that institutions are not exogenously given constraints but rather as the outcome of individual interactions.

\subsection{Evolution}

Darwinian evolution has endowed humans, like the other social species, with the need and the abilities to form societies, but, unlike most of these species, not with sufficiently complete instructions on what form of societies. Veblen embraced an evolutionary framework of explanation along Darwinian lines, involving multiple levels of explanation and emergent properties [19].

Veblen is the first scholar who applied Darwinian ideas to economics. On the basis of emphasizing reason (not purpose) should be used to explain ordered constantly change, he applied the three mechanisms of Darwinianism to economics. He saw a "Darwinistic account" in economics as addressing "the origin, growth, persistence, and variation of institutions". He wrote: "The growth of culture is a cumulative sequence of habituation" but "each new move creates a new situation which induces a further new variation in the habitual manner of response" and "each new situation is a variation of what has gone before and embodies as causal factors all that has been effected by what went before". In Veblen's theory, the mechanism of variation stands for promoting factor of institutional change, and inheritance is the key obstruction. However, existence of inheritance is also the basis of variation. In other words, although the description of the inheritance mechanism of institutional change and analysis of cause cumulative from Veblen close to the later concept of path dependence of North, the simple opposition between mechanism of inheritance and variation hindered in-depth analysis of institutional change theory.

For Veblen, the Darwinian rejection of teleology became the basis of a scientific and "post-Darwinian" approach to economic and social science. Veblen emphasized the need to have a detailed explanation of the causal processes behind human action. $\mathrm{He}$ held that such explanations of socio-economic evolution must involve individual agents as well as institutions and structures [20]. 


\section{Is there a group selection?}

Gene selections are central as the only units of replicator selection. Even kin selection is still indirectly driven by selfish gene behavior. Group or populations can also be viewed as vehicles of replicators, but far weaker, and less distinct, than individual physical colonies of genes or cells.

Group selection is a proposed mechanism of evolution in which natural selection is imagined to act at the level of the group. Some renowned scholars instead argue that since individuals can be regarded as populations of coordinated, cooperating genes, groups-as long as there is some degree of coordination and harmony in their partsshould be viewed as distinct "organisms" that can act as vehicles of natural selection.

In social science sphere, weak ties are actually vital for an individual's integration into modern society, it induces people to select as group rather than natural selection. Hayek made it quite clear that he saw group selection as the most important mechanism of cultural evolution [21]. He wrote that "cultural evolution is founded wholly on group selection". Groups with more efficient rules and orders tend to grow and multiply, while groups with less efficient rules and orders tend to perish and disappear. On Hayek's view, cultural evolution is a matter of natural selection operating on the order of the group. Since the order is produced in part by the rules followed by group members, selection operates indirectly on characteristics that may be acquired. It should be said that Hayek occasionally gave the impression that cultural evolution works through imitation rather than natural selection.

Group selection is an important mechanism of cultural evolution which indirectly influences institutional change. Culture may represent a group-level adaption that helps populations of humans adapt to environmental changes.

\section{Is the variation random or intentional?}

Although scholars have different views about gene selection and group selection, economists believe that group selection play an important role in evolution. Cultural evolution works through imitation rather than natural selection. Is the variation random or intentional?

Darwinism upholds that the variation is intentional, and the evolution of organisms and complex systems involves the mechanisms of variation, inheritance and selection. Darwinian evolution occurs when there is some replicating entity that makes imperfect copies of itself and these copies do not have equal potential to survive [22]. Some researches attempt to explain the emergence of institutions starting from an institution-free state of nature. Spontaneous order is an important theory of evolution. The emergence and variation of institution could be random or intentional. Hayek defines a spontaneous order, a "grown", "self-generating", or "endogenous" order, is one that has evolved without deliberate intervention. The spontaneous order, like any other order, emerges as a result of individual action, but unlike the artificial order it was not designed; but an artificial order "has been made by somebody putting the elements of a set in their places or directing their movements", like the order of a battle. Such an order can be imposed on a group, presumably, by directing the members to follow certain 
rules.

Hayek maintained spontaneous orders evolve in a process of cultural evolution in which natural selection operates on the order of the group. He said that "what may be called the natural selection of rules will operate on the basis of the greater or lesser efficiency of the resulting order of the group".

However, neo-institutionalists argued that his variation is random. Schumpeter argued that capitalist economies evolve not smoothly but discontinuously. Schumpeterian evolutionary change is punctuated rather than gradual-the disruptions of entrepreneurial innovation occur, as Schumpeter put it, at "irregularly regular" intervals. Columba to presents that when the outside pressure is an ideological break, and certain conditions are met, then the institutional environment undergoes radical change [23].

\subsection{Path of Institutional Changes}

Important strands of research have tended to contrast three kinds of opposing institutional emergence: those that emerge entirely spontaneously, those that are constructed and imposed by outsiders; and those that are indigenously introduced but exogenous in nature [24]. Different institutional emergence have different path of institutional change. Institutional change was triggered by a situation in which these individual game-models were no longer to be taken for granted because of quasi-endogenous changes in the objective game-form. Social, political, economic and organizational factors interact rather than they operate in unidirectional manner.

Overall, path of in institutional change have two ways: Demand Induced ChangeBottom-up Change or Supply Induced Changes: Change from Above and From Outside.

\section{Demand Induced Change: Bottom-up Change}

Andrew Schotter define "economics as the study of how individual economic agents pursuing their own selfish ends evolve institutions as a means to satisfy them", also emphasis is on a "bottom up" approach. Changing demographics and environmental conditions, technological change, or fresh information are typical ways of Bottom-up Change.

Some researchers link the development of institutions with changing demographics and environmental conditions [25]. This hypothesis suggests that institutional change is due to changes in the institutional environment that led to changes in the pattern of interests between economic entities or action groups. Davis and North both hold this kind of view, they believed that institutional environment and arrangement will cause its change. Moreover, institutions in place might become accustomed with new or increased demands that result from demographic and environmental changes. Ohlsson connect social adaptive ability along with demographic and environmental changes [26]. The conception could be applied to the theory related to institutional change also. Taking into consideration the framework of institutions it is highly argued that demand unaccompanied is inadequate for producing co-operative institutes. The individuals need to be highly noticeable to each other for reducing the sternness of the assurance problem and free rider. Such discussion is helpful for debate related to institutional change. 
Institutional change is an interactive process of technological change and institutional change. The launch of parameter "information" connects institutional changes and technological change. The literature points towards the link amid institutional and technological change, whereby both impact one another and could persuade change of other. The changes in demands and technology make the resource highly important. As a result, changes in resource prices might result in institutional changes [27].

Fresh information is another factor that causes institutional change. According to Cooter, the individual or the society, are just partly informed regarding the "world" and the associations of objects and subjects within the globe to one another. Thus, not all elements are known. Communities and individuals set up institutions with their partial information. Moreover, new information related to the subjects and objects within the globe is altering the meaning of the position of the community and individual. Fresh information might set off new self-meaning, communication, procedures or technical modifications [28]. These eventually could result in either new institutions or manifestations of the already existing formal as well as informal institutions. Nevertheless, the emphasis on new information appears to be deficient, new information isn't the only reason behind the change. The individual holds several choices for responding to one model, or to select different models, decisions for likely reactions might modify the settings and could result in new self-meanings of the actor, or to new meanings of the social atmosphere related to the actor [29]. Yet again the new self-definition might result in new procedures that might modify informal and formal models. Thus, structural reproduction along with "an irreducible present" may result in changes.

Maddison gives an example of printing to show how new technology induce meaning change. The first European university was created in Bologna in 1080, till 1455 when Gutenberg printed his first book, printing made books much cheaper. Publishers were much more willing to risk dissemination of new ideas and to provide an outlet for new authors. The proportion of the population with access to books was greatly increased, and there was a much greater incentive to acquire literacy. This eventually leads to Renaissance, and the 17th century scientific revolution and the 18th century enlightenment. Western elites gradually abandoned superstition, magic and submission to religious authority.

\section{Supply Induced Changes: Change from Above and From Outside}

The demand approach towards institutional change doesn't consider the fact that change could be inflicted from above. The supply-side change could either be encouraged from above, inside the institution, or through outsiders. Change from above and from outside always happens in the countries where they have powerful people or strong centralization.

Powerful people discontented with the present position could govern the procedure of institutional change [30]. Moving ahead, the emphasis on power with respect to institutional change enables a combination of supply and demand strategies for induced institutional change. Thus, the emphasis on the function of power relations and power structures is important for analyzing institutional change [31]. 
It is argued that institutional change might take place due to advancements in knowledge supply regarding economic and social behavior, organization and change according to powerful people's meaning. As a result, outside knowledge doesn't essentially modify the entire institutions but just fractions that are directly impacted through fresh knowledge. Nevertheless, for these fractions the knowledge is offered from above as well as the changes are executed in a top-down manner.

The researchers divide community with its institutions into border and center. In theory the center includes individually and hierarchical arranged institutions; the border involves voluntary arranged institutions. It is argued that the center is highly rigid in its institutional habits casing and no change arises from center, all innovations come from within.

\section{Entrepreneurship and Institutional Change}

During the past twenty years, there has been an explosion of new interest in entrepreneurs and their activities. There is now increasing focus, both in academic and policy realms, on the entrepreneur as the driver of economic growth [32]. Different views about the definition and category of entrepreneurship still exist, and analysis of the relationship between institutional change and entrepreneurship is still limited.

\subsection{Definition of Entrepreneurship}

Numerous visions have been articulated about the definition of the entrepreneur in economy. Three main views of the notion of the entrepreneurial process are important: Schumpeter's view of the entrepreneur as innovator, Kirzner's notion of entrepreneurship as arbitrage and the view of entrepreneurship in history as one of betting on ideas.

Schumpeter views entrepreneur as innovator who is an agent of change that is the source of his famous creative destruction [33]. He introduces a new good or a new method of production, opens a new market or discovers a new source of supply, or carries out a new organization of an industry [34]. His "Creative Destruction" vividly characterized innovation as "industrial mutation", which incessantly revolutionizes the economic structure from within, incessantly destroying the old one, incessantly creating a new one. Similarly, Kirzner describes that the Schumpeterian entrepreneur does not passively operate in a given world, and he creates a world different from which he finds [35]. An adverse view is that at earlier stages of development, entrepreneurship may play a less pronounced role because growth is largely driven by factor accumulation.

Schumpeterian entrepreneurs are mostly the various groups of firms that were concentrated in high-growth industries and generally exploited distinctive ideas; founders of each group of firms were invariably highly educated [36]. In addition to being an innovator, Schumpeter also emphasizes the entrepreneur is a leader. His actions channel the means of production into previously unexploited markets and other producers follow him into these new markets [37]. There are different impetus of Schumpeterian entrepreneurship: the role of risk taking, managerial ability, wealth [38], and preferences for the control, flexibility and other job attributes that come with being one's 
own boss.

Enormous literatures view Kirzner's notion of entrepreneurship as arbitrage. Kirzner implies that individuals secure entrepreneurial profits on the basis of knowledge and information gaps that arise between people in the market [35]. Kirznerian entrepreneur is an alert person, discovering opportunities by acting as an arbitrageur or a price adjuster in the marketplace, capitalizing on knowledge or information asymmetries. Kirzner's entrepreneur is alert to arbitrage opportunities based on past errors and serves to exploit and correct those errors, and in doing so, directs the market towards equilibrium.

However, Kirzner argues that a number of those who have commented on his work have misunderstood certain aspects of his theoretical system. He clarified if spite of the contrast with Schumpeter which he emphasized in 1973, the truth is that his understanding of the dynamic market process certainly can and should also encompass the consequences of Schumpeterian entrepreneurship. Like what he said in The Alert and Creative Entrepreneur: A Clarification [35].

My entrepreneurs were engaged in arbitrage, acting entrepreneurially even when they might not be seen as Schumpeterian "creators". Its focus was upon the dynamic competitive-entrepreneurial process driven by such alertness. It was only because the nature of this process is seen more clearly by paying attention to entrepreneurial alertness, that it was necessary to identify its presence in the individual decision... The "merely alert" entrepreneur identified in my work was never intended as an alternative to the creative, innovative Schumpeterian entrepreneur. But this did not imply any denial of the creativity of real-world entrepreneurship. It did not deny that, as a result of such creativity and speculation, the dynamics of capitalism can be seen as including movements towards new, hitherto unimagined patterns for possible equilibration.

It's obvious that his emphasis on the entrepreneur as the agent driving the competitive-equilibrative forces of the market, focuses attention on the entrepreneur not as a creator, but as being merely alert. As Mises whose he was expounding and developing, he also makes no reference to entrepreneurial innovation, creativity, or the like. He refers only to the entrepreneur's ability to "see" future prices more correctly than others see them.

But this did not imply any denial of the creativity of real-world entrepreneurship. In contrast, Kirzner's entrepreneurship encompasses the consequences of Schumpeterian entrepreneurship. Kirzner summarized two alternative, mutually-exclusive ways of entrepreneurial process: 1) a Schumpeterian view of this process as a series of disruptive episodes of "creative destruction", one driven by creative, innovative, entrepreneurial ventures, or 2) as a view, movements are seen as equilibrative entrepreneurial reactions to autonomous changes in the underlying supply and demand conditions.

Although both Schumpeter's and Kirzner's notions of entrepreneurship are grounded in the exploitation of profit opportunities, the greatest difference is that the former shifts the market away from equilibrium while the latter serves to continually move the market toward equilibrium, their concerns are different. Schumpeter's entrepreneur is an innovator who destroys the current structure, Kirzner's entrepreneur is alert to arbi- 
trage opportunities based on past errors and serves to exploit and correct those errors, and in doing so, directs the market towards equilibrium [24].

The third view of entrepreneurship is the notion of entrepreneurship in history as one of "betting on ideas". This notion concludes that a number of institutions facilitated entrepreneurs in their role as risk takers and innovators. That is, the rules of the game provided the stability and incentive for individuals to take risks. This view of definition could be explained why the plight of developing countries, it is critical to understand that it is not a lack of entrepreneurship that is the problem, but rather the institutional context directing entrepreneurial activities toward perverse ends.

There are also some other kinds of definition reflected in the categories of behavioral, occupational, and synthesis definitions [29]. Behavioral definitions also stress the risktaking dimension of entrepreneurship. Kanbur described the entrepreneur as one who "manages the production function" by paying workers wages (which are more certain than profits) and shouldering the risks and uncertainties of production. Such definitions are seen as very relevant for developing country contexts characterized by high risk and uncertainty. A synthesis definition has been offered by Gries and Naudédefines entrepreneurship as "the resource, process and state of being through and in which individuals utilize positive opportunities in the market by creating and growing new business firms". Shane and Venkataraman define an "opportunity" as when goods can be sold at a profit. From a development perspective this is inadequate because it implies that utility from entrepreneurship depends only on monetary gains [39].

\subsection{Categories of Entrepreneurs}

Entrepreneurship is an extremely complex and multidimensional phenomenon and not a single unified process [40]. Different kinds of categories have been given: productive, unproductive and destructive entrepreneurs [28]; replicative entrepreneurs and innovative entrepreneurs [30]; productive, unproductive and evasion entrepreneurs [3].

Baumol was the first scholar to make the distinction among productive, unproductive and destructive entrepreneurship. He defines entrepreneurs as "persons who are ingenious and creative in finding ways that add to their own wealth, power, and prestige". Innovation can be perceived as a productive contribution from entrepreneurs, financial activities which facilitate production, or any activities which contribute to producing goods and services. Foss and Foss add to this by introducing the element of new discovery, referring to "productive entrepreneurship" as the discovery of new attributes, opportunities, procedures and the like, where the discovery leads to an increase in joint surplus. A key idea in defining unproductive and destructive entrepreneurship is that not everything that is entrepreneurial is necessarily desirable. Often, an entrepreneur makes no productive contribution to the real output of an economy, and in some cases even plays a destructive role Baumol. Unproductive and destructive entrepreneurship can take many forms. These include, but are not limited to, rent seeking, illegal activities and shadow activities, and different forms of corruption. Although likely to be profitable, illegal or informal types of entrepreneurial behaviour are seen as unproduc- 
tive because little, if any, value is added to the economy and society. Illegal entrepreneurial behaviour will have a destructive role in an economy in the cases when these activities attract followers.

Many scholars accepts this category, as Sauka and Welter points that no consensus on the question of which activities can actually be regarded as productive, unproductive or destructive exists. The key challenge here is that in practice there are only a few genuine "unproductive entrepreneurship activities".

However, several empirical studies show that legal and illegal activities coexist and most new and small firms are actually involved both in productive and unproductitive activities at the same time. As Davidsson argues "unproductive entrepreneurship activity" can also lead to some positive output on both a venture and societal level, whereas "productive entrepreneurship activity" will not necessarily lead to a successful company performance or its contribution to society.

Another subdivision is between "replicative" entrepreneurs and "innovative" entrepreneurs. A replicative entrepreneur is someone who organizes an enterprise of a variety that has been launched many times before, and of which many other examples are currently extant. The innovative entrepreneur, as the name implies, does something that has not been done before. Like Baumol, Powell suggests that entrepreneurship of the "imitative" or "low order" form is needed to meet basic human needs of persons in the developing world. A number of other studies have explored the overall relationship between entrepreneurship and employment growth.

A new distinction among productive, unproductive and evasion entrepreneurs was made. Productive activities-arbitrage and innovation-constitute the very essence of economic growth and progress. When undertaking productive activities, entrepreneurs drive economic growth through arbitrage and innovation. In contrast, unproductive activities include those that benefit the entrepreneur but harm society in general. Examples include crime, rent seeking, and other behaviors that destroy existing resources. About productive and unproductive activities, evasive activities include the expenditure of resources and efforts in evading the legal system or in avoiding the unproductive activities of other agents.

Evasive entrepreneurship was first used by Coyne and Leeson, "Evasive activities include the expenditure of resources and efforts in evading the legal system or in avoiding the unproductive activities of other agents". Niklas Elerta and Magnus Henreksona presents their definition: "Evasive entrepreneurship is profit-driven business activity in the market that introduces Schumpeterian technological or organizational innovations, in order to exploit opportunities in a Kirznerian (arbitrage) manner by evading the existing institutional framework".

\subsection{Entrepreneurship and Institutional Change}

Most of researches about the relationship of entrepreneurship and institutional change are how nation's institution or economic policy influence entrepreneurship, and how entrepreneurs' actives make the economy successful or unsuccessful. Recently, a few 
researchers began to focus on the influence of entrepreneurs' actives or ideas on institutional change, especially in developing countries where property rights and the rule of law do not exist or are poorly defined or enforced.

The Austrians have long realized the importance of the entrepreneur and the need for economic analysis of the institutional organization that influences economic actors. Schumpeter recognized that the entrepreneur (in addition to all economic actors) would have to adapt to his surrounding institutional environment. The entrepreneur, working within the societal institutional framework will adjust and adopt his actions based on the incentive structure he faces.

Scholars from four kinds of policy confirm the relationship between institutional change and entrepreneurship. The degree of benefit of entrepreneurs' activities to the society are very heavily influenced by current social institutions and legal structure, suggesting immediately that this is a matter that merits the attention of those in government who design economic policy. In addition, the misallocation of entrepreneurship can and often does result from government action. Often such action is driven by vested interests.

Unofficial economy is a good example to explain this reason. Several studies attempt to measure the unofficial economy. By analyzing the "unofficial economy", it is clearly to see an underground economy in those countries where property rights and the rule of law do not exist or are poorly defined or enforced. Extralegal activities evolve in order to circumvent the current institutional structure that prevents or retards key economic activities. This usually causes the prohibition of certain transactions, or the failure to enforce transactions because of poorly defined property rights or rule of law [41].

Baumol also offers an example that in India, a substantial number of industries, firms were required to provide estimates of their production the following year, some industries have legal restrictions on the use of computers. The result was incredible poverty that began to be rolled back (and allowed India to achieve striking growth), only when these regulations were weakened or eliminated and the market received some freedom, changing the structure of the incentives offered to entrepreneurs.

One role of the state that has received more attention is in industrial policy. Here, old models of import-protection and state-owned enterprises have made place for policies that rely more on the private sector and entrepreneurship, but with government still playing an important role to address market failures in the entrepreneurial start-up and growth process.

Taxing is third policy that will induce enormous influence on entrepreneurs. De Meza and Webb make the case that credit market imperfections may lead to "overinvestment" when banks cannot accurately judge entrepreneurial ability. Because banks cannot observe any entrepreneur's ability ex ante, interest rates on start-up capital will reflect average entrepreneurial ability. If the proportion of entrepreneurs of low ability increases, it will result in higher borrowing costs, which impose a negative externality on entrepreneurs of high ability, who will consequently borrow and invest less. The entry of entrepreneurs with low ability might also hinder development because such en- 
trepreneurs may have less productive workers, who will earn reduced wages as a result, and in turn reduce the opportunity costs of self-employment, thereby causing the entry of even more low-ability entrepreneurs.

Kirzner points that prices systematically in directions tend to eliminate the price differentials which are, always, the sparks which ignite entrepreneurial attention, drive, and creativity. That's why he prefers to focus the definition of entrepreneurs on alertness rather than innovation:

To be sure, creativity is much more than alertness. But the creativity that drives profit-winning entrepreneurial behavior is a creativity that embraces alertness too - alertness to present and future price patterns, alertness to new technological possibilities, and alertness to possible future patterns of demand. Public policies that tend to promote alertness, are policies which tend to promote creativity.

Most empirical studies on the relationship between entrepreneurship and economic development have mainly been entrepreneurs' influence on economic growth. Following Leff many development scholars took the position that "entrepreneurship is no longer a problem" or a "relevant constraint on the pace of development" in developing countries.

Macro-level empirical work mainly has been concerned with how entrepreneurship influences economic measures of development, such as GDP, productivity, and employment. The U-shaped relationship implies a higher rate of entrepreneurial activity in low-income countries than in middle-income countries. This result may reflect that entrepreneurs in developing countries are less innovative and tend to be proportionately more "necessity" motivated. Higher levels of GDP may therefore be associated with more "innovative" forms of entrepreneurship.

Most micro-level studies focus on the why and how of entrepreneurship, not its impact on development. As these findings refer to the impact of the average entrepreneur, it perhaps suggests that focusing on the average entrepreneur may not be the best policy stance. It may be better to focus on the small subset of innovative entrepreneurs that do make a difference. Studies find that innovative firms, particularly in high-tech sectors, have on average higher levels of productivity, tend to do enjoy higher employment growth, and cause positive spillovers for other firms.

However, for the Austrians, entrepreneurship is an omnipresent aspect of human action such that all individuals are entrepreneurs. Given this, entrepreneurship cannot be the cause of economic development. Entrepreneurship cannot be the cause of development, but rather, that the type of entrepreneurship associated with economic development is a consequence of it. That is, development is caused by the adoption of certain institutions, which in turn channel and encourage the entrepreneurial aspect of human action in a direction that spurs economic growth.

Recently researches pay more attention on the influence of entrepreneurs' actives on institutional change, especially in developing countries where property rights and the rule of law do not exist or are poorly defined or enforced. The new insight is that some of those activities have been unproductive or even seriously damaging to the general 
welfare. Entrepreneurship can contribute to multi-dimensional well-being by what people can achieve through their capabilities. Individual level data from the Global Entrepreneurship Monitor (GEM) show evidence of an inverse U-shape relationship between entrepreneurship and national happiness. Opportunity-motivated entrepreneurship may contribute to a nation's happiness, but only up to a point. Whereas scholars viewed entrepreneurship initially as being restricted to innovation and business creation, the view has expanded towards one where entrepreneurship is seen more appropriately as a social phenomenon that reflects the broader institutional characteristics of a society. Entrepreneurship is not only concerned with business success, as measured by profits, but also with subjective welfare and non-economic wellbeing. Entrepreneurship is a catalyst for structural change and institutional evolution.

Evasive entrepreneurs are viewed as a new rule-breaker. In most theories of institutions and entrepreneurship, causality is understood to run from institutions to entrepreneurship. Some scholars thus conclude that institutions are the main determinants of entrepreneurship. Schumpeterian considers the entrepreneur as a rule-breaker, and Kirzner considers the entrepreneur as an arbitrageur.

Evasive entrepreneurship has been considered to be possibly its dynamic character, which can remedy the inertia of political and economic institutions. In times of rapid change, driven for example by a high rate of technological progress or new supplies of resources, economic adaptability may be difficult or impossible when actors abide by existing institutions. In such circumstances, evasive entrepreneurship can prevent existing institutions from stifling economic development:

Formal institutions may prevent or raise the cost of exploiting business opportunities, but are often rife with contradictions. Such contradictions can trigger evasive behavior because entrepreneurs may earn large rents by using their innovations to exploit them, thereby circumventing institutional impediments. While evasive entrepreneurship can either be productive or unproductive/destructive, it may prevent economic development from being stifled by existing institutions during times of rapid economic change. Evasive entrepreneurship becomes sufficiently economically important, it may trigger a response from lawmakers and regulators, leading to institutional change with potentially important welfare implications.

\section{Conclusions}

This literature argues that institution is not only the rule in a hierarchical order, but also a rule as something spontaneously and endogenously shaped and sustained in the repeated operational plays of the game itself. Culture and meaning are important in the definition of institution. An institution conceptualized is essentially endogenous, but appears to be an exogenous constraint to the individual agents. Paths of in institutional change have two ways: Demand Induced Change-Bottom-up Change or Supply Induced Changes: Change from above and from outside. Entrepreneurship does an important role during institutional change.

Most of researches focus on how institution influences on entrepreneurship, how 
economic policy influences entrepreneurship, and how entrepreneurs' actives make the economy successful or unsuccessful.

However, entrepreneurship is not only concerned with business success, as measured by profits, but also with subjective welfare and non-economic wellbeing. Entrepreneurship is a catalyst for structural change and institutional evolution. Evasive entrepreneurs could be viewed as a new rule-breaker.

\section{References}

[1] Hayek, F.A. (1967) The Evolution of the Rules of Conduct. 2nd Edition, The University of Chicago Press, Chicago.

[2] Masahiko, A. (2001) Towards a Comparative Institutional Analysis. 2nd Edition, The MIT press, Massachusetts.

[3] Elert, N. and Henrekson, M. (2014) Evasive Entrepreneurship and Institutional Change. Research Institute of Industrial Economics in Its Series Working Paper Series with Number 1044. http://dx.doi.org/10.2139/ssrn.2513475

[4] Searle, J.R. (2005) What Is an Institution? Journal of Institutional Economics, 50, 132-157. http://dx.doi.org/10.1017/s1744137405000020

[5] Hodgson, G.M. (2002) The Evolution of Institutions: An Agenda for Future Theoretical Research. Constitutional Political Economy, 13, 57-73. http://dx.doi.org/10.1023/A:1015301101712

[6] North, D. (1990) Institutions. The Journal of Economic Perspectives, 5, No. 1.

[7] Nelson, R.R. (2002) Bringing Institutions into Evolutionary Growth Theory. Journal of Evolutionary Economics, 12, 17-28. http://dx.doi.org/10.1007/s00191-002-0108-x

[8] Pelikan, P. (1989) Evolution, Competence, and Market for Control. Journal of Economic Behavior and Organization, 12, 108-123. http://dx.doi.org/10.1016/0167-2681(89)90024-3

[9] Joel, M. (2010) Culture, Institutions, and Modern Growth. Conference on Understanding Institutions and Development Economics. The Legacy and Work of Douglass C. North, St. Louis, 4-6 November 2010, 151-186.

[10] Boettke, P.J., Coyne, C.J. and Leeson, P.T. (2004) The Plight of Underdeveloped Countries. Cato Journal, 24, 3.

[11] McCloskey, D.N. (2010) Bourgeois Dignity: Why Economics Can't Explain the Modern World. 2nd Edition, University of Chicago Press, Chicago.

[12] Smith, A. (1986) The Wealth of Nations. 3rd Edition, Penguin Classics, New York.

[13] Sen, A. (2008) Rational Behavior. 2nd Edition, The New Palgrave Dictionary of Economics.

[14] McCloskey, D.N. (2009) Max U vs. Humanism: A Critique of Neo-Institutionalism. 2nd Edition, University of Chicago Press, Chicago.

[15] Giddens, A. (1984) The Constitution of Society. 3rd Edition, University of California Press, California.

[16] Schutz, A. and Luckman, T. (1973) The Structures of the Life-World. 2nd Edition, Northwestern University Press, Chicago.

[17] Grannovetter, M.S. (1973) The Strength of Weak Ties. American Journal of Sociology, 78, 1360-1380. http://dx.doi.org/10.1086/225469

[18] Schutz, A. (1967) The Phenomenology of the Social World. 2nd Edition, Northwestern University Press, Chicago. 
[19] Hodgson, G.M. (1998) On the Evolution of Thorstein Veblen's Evolutionary Economics. Cambridge Journal of Economics, 22, 53-73. http://dx.doi.org/10.1093/oxfordjournals.cje.a013726

[20] Hodgson, G.M. (2005) Generalizing Darwinism to Social Evolution: Some Early Attempts. Journal of Economic Issues, 40, 234-253. http://dx.doi.org/10.1080/00213624.2005.11506859

[21] Angner, E. (2002) The History of Hayek's Theory of Cultural Evolution. Studies in History and Philosophy of Science Part C: Studies in History and Philosophy of Biological and Biomedical Sciences, 28, 80-95. http://dx.doi.org/10.1016/s1369-8486(02)00024-9

[22] Hodgson, G.M. (2002) Darwinism in Economics: From Analogy to Ontology. Journal of Evolutionary Economics, 38, 132-145. http://dx.doi.org/10.1007/s00191-002-0118-8

[23] Colombatto, E. (2002) Towards a Quasi-Lamarckian Theory of Institutional Change. Professor. Università di Torino and ICER.

[24] Boettke, P.J. and Coyne, C.J. (2003) Entrepreneurship and Development: Cause or Consequence? Advances in Austrian Economics, 6, 67-88. http://dx.doi.org/10.1016/S1529-2134(03)06005-8

[25] Greif, A. (2006) Institutions and the Path to the Modern Economy: Lessons from Medieval Trade. Cambridge University Press, Cambridge. http://dx.doi.org/10.1017/CBO9780511791307

[26] Olson, M. (1996) Big Bills Left on the Sidewalk: Why Some Nations are Rich and Others Poor. Journal of Economic Perspectives, 10, 88-109. http://dx.doi.org/10.1257/jep.10.2.3

[27] Grannovetter, M.S. (1985) Economic Action and Social Structure: The Problem of Embeddedness. American Journal of Sociology, 91, 481-510. http://dx.doi.org/10.1086/228311

[28] Baumol, W.J. (2008) Entrepreneurs, Inventors and the Growth of the Economy, Part of the Supplemental Materials for Innovation and U.S. Competitiveness. The Conference Board Report \#R-1441-09-RR.

[29] Gries, T. and Naudé, W.A. (2011) Entrepreneurship and Human Development: A Capability Approach. Journal of Public Economics, 95, 216-224. http://dx.doi.org/10.1016/j.jpubeco.2010.11.008

[30] Baumol, W.J. (1990) Entrepreneurship: Productive, Unproductive and Destructive. Journal of Political Economy, 98, 893-921. http://dx.doi.org/10.1086/261712

[31] Bowles, S., Choi, J.-K. and Hopfensitz, A. (2003) The Co-Evolution of Individual Behaviors and Social Institutions. Journal of Theoretical Biology, 223, 99-112. http://dx.doi.org/10.1016/S0022-5193(03)00060-2

[32] Coyne, C.J. and Leeson, P.T. (2004) The Plight of Undeveloped Countries. Cato Journal, 24, 235-249.

[33] Schumpeter, J.A. (1942) Capitalism, Socialism and Democracy. Vol. 36, Harper \& Row, New York, 132-145.

[34] Ohyama, A., Braguinsky, S. and Klepper, S. (2009) Schumpeterian Entrepreneuship. Atlanta Competitive Advantage Conference Paper.

[35] Kirzner, I.M. (1973) Competition and Entrepreneurship. 2nd Edition, University of Chicago Press, Chicago.

[36] Anderson, A.R. and Smith, R. (2007) The Moral Space in Entrepreneurship: An Exploration of Ethical Imperatives and the Moral Legitimacy of Being Enterprising. Entrepreneurship \& Regional Development, 19, 479-497. http://dx.doi.org/10.1080/08985620701672377

[37] Schumpeter, J.A. (1961) The Theory of Economic Development. 3rd Edition, Oxford Uni- 
versity Press, New York.

[38] Evans, D.S. and Jovanovic, B. (1989) As Estimated Model of Entrepreneurial Choice under Liquidity Constraints. Journal of Political Economy, 97, 808-827. http://dx.doi.org/10.1086/261629

[39] Shane, S. (1997) Who Is Publishing the Entrepreneurship Research? Journal of Management, 23, 83-95. http://dx.doi.org/10.1177/014920639702300105

[40] Hannafey, F.T. (2003) Entrepreneurship and Ethics: A Literature Review. Journal of Business Ethics, 46, 98-108. http://dx.doi.org/10.1023/A:1025054220365

[41] Murphy, K., Schleifer, A. and Vishny, R. (1991) The Allocation of Talent: Implications for Growth. The Quarterly Journal of Economics, 106, 503-530.

http://dx.doi.org/10.2307/2937945

Submit or recommend next manuscript to SCIRP and we will provide best service for you:

Accepting pre-submission inquiries through Email, Facebook, LinkedIn, Twitter, etc. A wide selection of journals (inclusive of 9 subjects, more than 200 journals)

Providing 24-hour high-quality service

User-friendly online submission system

Fair and swift peer-review system

Efficient typesetting and proofreading procedure

Display of the result of downloads and visits, as well as the number of cited articles Maximum dissemination of your research work

Submit your manuscript at: http://papersubmission.scirp.org/ 